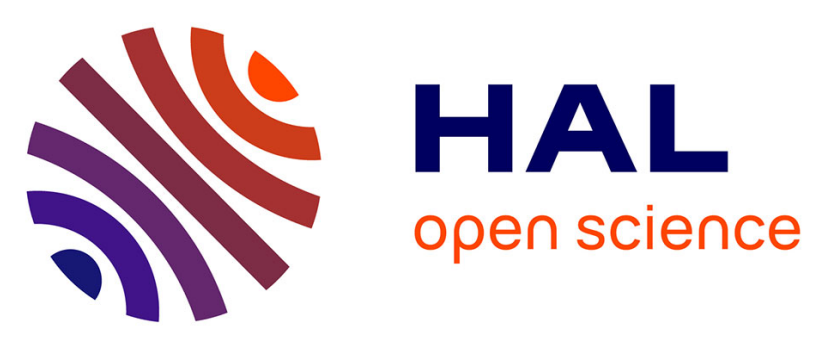

\title{
Compatibility at amino acid position 98 of MICB reduces the incidence of graft-versus host disease in conjunction with the CMV status
}

Raphaël Carapito, Ismail Aouadi, Angelique Pichot, Perrine Spinnhirny, Aurore Morlon, Irina Kotova, Cécile Macquin, Véronique Rolli, Anne Cesbron, Katia Gagne, et al.

\section{To cite this version:}

Raphaël Carapito, Ismaïl Aouadi, Angelique Pichot, Perrine Spinnhirny, Aurore Morlon, et al.. Compatibility at amino acid position 98 of MICB reduces the incidence of graft-versus host disease in conjunction with the CMV status. Bone Marrow Transplantation, 2020, 15, Online ahead of print. 10.1038/s41409-020-0886-5 . inserm-02545513

\section{HAL Id: inserm-02545513 https://www.hal.inserm.fr/inserm-02545513}

Submitted on 17 Apr 2020

HAL is a multi-disciplinary open access archive for the deposit and dissemination of scientific research documents, whether they are published or not. The documents may come from teaching and research institutions in France or abroad, or from public or private research centers.
L'archive ouverte pluridisciplinaire HAL, est destinée au dépôt et à la diffusion de documents scientifiques de niveau recherche, publiés ou non, émanant des établissements d'enseignement et de recherche français ou étrangers, des laboratoires publics ou privés. 
Compatibility at amino acid position 98 of MICB reduces the incidence of graft-versushost disease in conjunction with the CMV status

Running head: MICB, CMV and GVHD in HCT

Raphael Carapito ${ }^{1,2,3,4}$, Ismail Aouadi ${ }^{1,2,3}$, Angélique Pichot $^{1,2,3}$, Perrine Spinnhirny ${ }^{1,2,3}$, Aurore Morlon $^{2,5}$, Irina Kotova ${ }^{2,5}$, Cécile Macquin ${ }^{1,2,3}$, Véronique Rolli ${ }^{1,2,3}$, Anne Cesbron ${ }^{2,6,7,8}$, Katia Gagne $^{2,6,9}$, Machteld Oudshoorn ${ }^{10,11}$, Bronno van der Holt ${ }^{12}$, Myriam Labalette ${ }^{13,14}$, Eric Spierings ${ }^{15}$, Christophe Picard ${ }^{16}$, Pascale Loiseau ${ }^{2,7,17}$, Ryad Tamouza ${ }^{2,17}$, Antoine Toubert $^{2,7,17}$, Anne Parissiadis ${ }^{7,18}$, Valérie Dubois ${ }^{19}$, Catherine Paillard ${ }^{1,2,7,20}$, Myriam MaumyBertrand $^{21}$, Frédéric Bertrand ${ }^{21}$, Peter A. von dem Borne ${ }^{22}$, Jürgen H.E. Kuball ${ }^{23}$, Mauricette Michallet $^{7,24}$, Bruno Lioure ${ }^{7,25}$, Régis Peffault de Latour ${ }^{2,7,26}$, Didier Blaise ${ }^{7,27}$, Jan J. Cornelissen $^{28}$, Ibrahim Yakoub-Agha ${ }^{7,14}$, Frans Claas $^{11}$, Philippe Moreau ${ }^{7,29}$, Dominique Charron $^{1,2,17}$, Mohamad Mohty $7,30,31,32$, Yasuo Morishima ${ }^{33}$, Gérard Sociée, ${ }^{2,25}$, and Seiamak Bahram ${ }^{1,2,3,4}$

1 Laboratoire d'ImmunoRhumatologie Moléculaire, INSERM UMR_S1109, Plateforme GENOMAX, Faculté de Médecine, Fédération Hospitalo-Universitaire OMICARE, Fédération de Médecine Translationnelle de Strasbourg (FMTS), Université de Strasbourg, Strasbourg, France.

2 Labex TRANSPLANTEX, Faculté de Médecine, Université de Strasbourg, Strasbourg, France.

3 INSERM Franco-Japanese Nextgen HLA laboratory, Nagano, Japan and Strasbourg, Strasbourg, France.

4 Laboratoire d'Immunologie, Plateau Technique de Biologie, Pôle de Biologie, Nouvel Hôpital Civil, Strasbourg, France.

5 BIOMICA SAS, Strasbourg, France. 
6 Etablissement Français du Sang (EFS) Centre-Pays de la Loire, Laboratoire HLA, Nantes, France.

7 Société Francophone de Greffe de Moelle et de Thérapie Cellulaire (SFGM-TC), Hôpital Edouard Herriot, $\mathrm{CHU}$, Lyon, France.

8 Société Francophone d'Histocompatibilité et d'Immunogénétique (SFHI), Paris, France.

9 INSERM 1232, CRCINA, Université Nantes-Angers, Nantes, France.

10 Europdonor operated by Matchis Foundation, Leiden, The Netherlands.

11 Department of Immunohematology and Blood transfusion, LUMC, Leiden, The Netherlands.

12 HOVON Data Center, Department of Hematology, Erasmus MC Cancer Institute, Rotterdam, The Netherlands.

13 Laboratoire d'Immunologie, CHRU de Lille, Lille, France.

14 LIRIC INSERM U995, Université Lille 2, Lille, France.

15 Laboratory for Translational Immunology, University Medical Center Utrecht, Utrecht, The Netherlands.

16 Aix-Marseille Université, CNRS, EFS-PACA, ADES UMR 7268, Marseille, France.

17 Laboratoire Jean Dausset, INSERM UMR_S 1160, Hôpital Saint-Louis, Paris, France.

18 Etablissement Français du Sang (EFS) Grand-Est, Laboratoire HLA, Strasbourg, France.

19 Etablissement Français du Sang (EFS) Rhône-Alpes, Laboratoire HLA, Lyon, France.

20 Service d'Hématologie et d'Oncologie pédiatrique, Hôpitaux Universitaires de Strasbourg, Strasbourg, France.

21 Institut de Recherche Mathématique Avancée, CNRS UMR 7501, LabEx Institut de Recherche en Mathématiques, ses Interactions et Applications, Université de Strasbourg, Strasbourg, France

22 Department of Hematology, Leiden University Medical Center, Leiden, The Netherlands. 23 Department of Hematology, University Medical Center Utrecht, Utrecht, The Netherlands. 24 Centre Hospitalier Lyon Sud, Hématologie 1G, Hospices Civils de Lyon, Pierre Bénite, Lyon, France. 
25 Service d'Hématologie Adulte, Hôpitaux Universitaires de Strasbourg, Strasbourg,

57 France.

5826 Service d'Hématologie - Greffe, Hôpital Saint-Louis, APHP, Paris, France.

5927 Institut Paoli Calmettes, Marseille, France.

6028 Department of Hematology and ErasmusMC Cancer Institute, Erasmus University

61 Medical Center, Rotterdam, The Netherlands.

6229 Service d'Hématologie Clinique, CHU Hôtel Dieu, Nantes, France.

6330 Hôpital Saint Antoine, Département d'Hématologie, Paris, France.

6431 Université Pierre \& Marie Curie, Paris, France.

6532 Centre de Recherche Saint-Antoine, INSERM UMR_S 938, Paris, France.

6633 Aichi Cancer Center Research Institute, Division of Epidemiology and Prevention, 1-1

67 Kanokoden, Chikusa-ku, Nagoya, Japan.

68

69 Correspondence: Seiamak Bahram and/or Raphael Carapito, both at Centre de Recherche d'Immunologie et d'Hématologie, 4 rue Kirschleger, 67085 Strasbourg Cedex France; emails: siamak@unistra.fr and/or carapito@unistra.fr 


\section{ABSTRACT}

75

Graft-versus-host disease (GVHD) and cytomegalovirus (CMV)-related complications are leading causes of mortality after unrelated-donor hematopoietic cell transplantation (UD-HCT). The non-conventional MHC class I gene MICB, alike MICA, encodes a stress-induced polymorphic NKG2D ligand. However, unlike MICA, MICB interacts with the CMV-encoded UL16, which sequestrates MICB intracellularly, leading to immune evasion. Here, we retrospectively analyzed the impact of mismatches in MICB amino acid position 98 (MICB98), a key polymorphic residue involved in UL16-binding, in 943 UD-HCT pairs who were allele-matched at HLA-A, $-B,-C,-D R B 1,-D Q B 1$ and MICA loci. HLA-DP typing was further available. MICB98 mismatches were significantly associated with an increased incidence of acute (grade II-IV: HR, 1.20; 95\% Cl, 1.15 to $1.24 ; P<0.001$; grade III-IV: HR, 2.28; $95 \% \mathrm{Cl}, 1.56$ to $3.34 ; P<0.001)$ and chronic GVHD $(\mathrm{HR}, 1.21 ; 95 \% \mathrm{Cl}, 1.10$ to 1.33 ; $P<0.001)$. MICB98 matching significantly reduced the effect of CMV status on overall mortality from a hazard ratio of 1.77 to 1.16 . MICB98 mismatches showed a GVHD-independent association with a higher incidence of CMV infection/reactivation $(\mathrm{HR}, 1.84 ; 95 \% \mathrm{Cl}, 1.34$ to $2.51 ; P<0.001)$. Hence selecting a MICB98-matched donor significantly reduces the GVHD incidence and lowers the impact of CMV status on overall survival. 


\section{INTRODUCTION}

Unrelated-donor hematopoietic cell transplantation (HCT) is an established treatment for a wide range of immunological and hematologic disorders, malignant or otherwise ${ }^{1}$. Although more than 50,000 HCTs are performed annually worldwide ${ }^{2,3}$, adverse clinical outcomes occur frequently. One of the most common life-threatening complications is graft-versus-host disease (GVHD), which greatly hampers the successful outcome of this powerful and sometimes unique curative option. In GVHD, the donor's immune cells attack the patient's organs and tissues, impairing their ability to function and increasing the patient's susceptibility to infection. The organs/tissues most frequently targeted are the skin, the gastrointestinal tract and the liver. Despite the availability of effective immunosuppressive drugs, the incidence of GVHD remains alarmingly high: up to $35 \%$ experience grade III-IV acute GVHD and $40 \%$ to $50 \%$ experience chronic GVHD ${ }^{4-6}$.

Cytomegalovirus (CMV) infection/reactivation represents another leading cause of morbidity and mortality in patients undergoing allogeneic HCT because it frequently causes serious complications, e.g., pneumonia, hepatitis, gastroenteritis, retinitis, and encephalitis ${ }^{7-11}$. Because of the immunosuppressive regimen, allogeneic HCT patients are indeed at a higher risk for CMV infection and/or reactivation. The incidence of CMV infection has been reported to vary between 40 and $80 \%$ in CMV seropositive allogeneic HCT patients not treated with anti-viral prophylaxis drugs, which currently represents most of the allogeneic HCT recipients 12-18. In seronegative patients receiving a transplant from a seropositive donor, the rate of primo infection is approximately $30 \%{ }^{12}$. Despite the implementation of prophylaxis, monitoring, and pre-emptive treatment of CMV reactivation/infection, cases of CMV seropositivity of the donor and/or the recipient show decreased 
survival rates compared to CMV-seronegative recipients who undergo allograft from CMV-seronegative donors ${ }^{16},{ }^{19}$. New strategies for preventing CMV reactivation/infection in transplant recipients therefore remain an important objective for the improvement of allogeneic HCT.

Increasing the degree of human leukocyte antigen (HLA) matching is one of the most important strategies to lower the risks of both GVHD and CMV infections. The former is a direct consequence of better HLA-matching, whereas the latter is an indirect effect due to the well-described association of CMV infection with GVHD occurrence ${ }^{20,21}$. However, even in genotypically HLA-matched donors and recipients, the incidence of grade III-IV acute GVHD and CMV reactivation/infection can be as high as $30 \%$ and $80 \%$, respectively ${ }^{13,22}$. For CMV infection/reactivation, other risk factors include age, source of stem cells, disease, and donor (D)/recipient (R) CMV serological status ${ }^{23,24}$.

The MHC-encoded non-conventional MHC class I chain-related (MIC) genes A (MICA) and $B$ (MICB) encode polymorphic cell surface proteins which bind to NKG2D; an activating immune receptor expressed by cytotoxic T and NK cells ${ }^{25}{ }^{26}$. This interaction is seminal in defense both against infections and malignancies. Moreover, $M I C B^{27,28}$ happens to be one of the most promising candidates to explain, at least partially, GVHD and CMV complications that cannot be attributed to classical HLA genes or the related MICA gene incompatibilities ${ }^{29-31}$. MICB is indeed highly polymorphic, with 47 alleles reported to date (http://www.ebi.ac.uk/ipd/imgt/hla/stats.html). It encodes a cell-surface glycoprotein up-regulated by cell stress ${ }^{25,32}$. The gene is located $130 \mathrm{~kb}$ and $83 \mathrm{~kb}$ centromeric to $H L A-B$ and MICA, respectively, and was discovered by us over 20 years ago ${ }^{25}$. MICB is highly similar to MICA in terms of sequence $(83 \%$ shared amino acid 
sequence identity), linkage disequilibrium with $H L A-B$, protein structure (HLA-like structure without association to $B_{2}$-microglobulin) and constitutive expression pattern (restricted to epithelial cells, fibroblasts, monocytes, dendritic cells and endothelial cells) ${ }^{26,33,34}$. MICB is a ligand for the activating NKG2D receptor expressed on the surface of cytotoxic $\mathrm{CD}^{+} \alpha \beta$ and $y \delta$ T lymphocytes and natural killer cells ${ }^{35}$. Interestingly, and in contrast to MICA, MICB binds the CMV protein UL16, which sequestrates MICB intracellularly in an immune escape mechanism ${ }^{36}$. Different MICB alleles are not equal with respect to binding to UL16. MICB*008 has been shown to have a decreased binding capacity to UL16 compared to other alleles ${ }^{37}$. $M I C B^{*} 008$ is characterized by a polymorphism at amino acid position 98 , causing an isoleucine (lle) to methionine (Met) exchange in the $\alpha 2$ domain of the MICB protein. The variation $\mathrm{Ile}>$ Met is exclusively present in $M I C B^{*} 008$ and is the unique polymorphic position that is in direct contact with UL16 through hydrophobic contacts (distance $<4.0 \AA$ ) with leucine 161 of UL16 ${ }^{38}$.

Several lines of evidence indicate that $M I C B$ could play a role in triggering GVHD and/or modulating CMV infection/reactivation: (1) the localized expression in epithelial cells of the gastrointestinal tract, whose damage during GVHD plays a major pathophysiologic role in the amplification of systemic disease ${ }^{39}$; (2) the common features with MICA that have repeatedly been shown to be involved in GVHD ${ }^{29}, 30,40-42$; and (3) the binding of MICB to the UL16 protein ${ }^{36}$. The present study hence aims to show the effect of $M I C B$ matching at amino acid position 98 , representing about $6 \%$ of transplantations, on the outcome of unrelated donor HCT in a cohort of 943 donor/recipient pairs matched for HLA-A, $-B,-C,-D R B 1,-D Q B 1$, and MICA. 


\section{PATIENTS AND METHODS}

\section{STUDY DESIGN AND OVERSIGHT}

This retrospective study was designed to test whether donor-recipient matching at amino acid position 98 of the MICB protein (MICB98) improves the outcome of unrelated HCT. Patients from six French and three Dutch centers and their donors were included; the unrelated donors originated from national or international donor registries. Genomic DNA samples and high-resolution $H L A-A,-B,-C,-D R B 1,-D Q B 1$, -DPB1 and MICA typing data were collected. Clinical information was made available by the SFGM-TC and the HOVON Data Center from the EBMT (European group for Blood and Marrow Transplantation) ProMISe patient database. All authors vouch for the accuracy and completeness of the results. This study, conducted under the auspices of SFGM-TC and the Dutch-Belgian Cooperative Trial Group for Hematology Oncology (HOVON), was approved by institutional review boards of the participating centers and was performed according to the principles of the Declaration of Helsinki. Written informed consent was obtained from all participants.

\section{PATIENTS AND DONORS}

The study population consisted of 943 patients who underwent unrelated HCT for the treatment of blood disorders between 2005 and 2013. All patients received a first allogeneic transplant using bone marrow or peripheral blood stem cells, and donorrecipients were matched for 12 of the 12 possible alleles at $H L A-A,-B,-C,-D R B 1$, DQB1, and MICA loci (Table 1).

\section{MICB GENOTYPING AT AMINO ACID POSITION 98}


The polymorphic nucleotide position 363 (C/G; rs3134900) causes an isoleucine (lle) to methionine (Met) change at amino acid position 98 in the $\alpha 2$ domain of the MICB protein. Both patients and unrelated donors were genotyped for this position by Sanger sequencing of MICB's exon 3, following previously described protocols ${ }^{43}$. The sequences were analyzed using Seqscape v2.6 (Life Technologies, USA) to assign genotypes.

\section{DEFINITIONS}

Grading of acute and chronic GVHD was performed according to the classification of Glucksberg et al. ${ }^{44}$. For acute GVHD, severe corresponds to grades III and IV. CMV positivity of the donor and/or the recipient was defined by the presence of anti-CMV $\lg G$ in the serum of the donor and/or the recipient. CMV reactivation was defined as the time from transplantation to the first CMV infection episode. In addition to clinical examination, CMV infection/reactivation episodes were characterized at a molecular level by a viral load $>10^{4}$ copies $/ \mathrm{ml}$ as determined by quantitative PCR on whole blood. Overall survival (OS) was defined as the time from transplantation to death by any cause. Relapse-free survival (RFS) was defined as the time to relapse of primary disease or death by any cause, whichever came first. Non-relapse mortality (NRM) corresponds to mortality within the first complete remission of disease. Causes of death unrelated to transplantation included deaths related to relapse, progression of the original disease, secondary malignancy, and cell therapy (non-HCT). OS, RFS, NRM, GVHD and CMV reactivation were censored at the time of the last follow-up. Incidences of clinical outcomes were defined as the cumulative probability of the outcomes at any given point. 


\section{STATISTICAL ANALYSIS}

219 After validating that the data meet requested assumptions, the distribution of each covariate between the MICB98 matched and mismatched groups was assessed by Pearson's Chi square test or Fisher's exact test for small sample sizes. The variances between the two groups were similar for the different variables assessed in our models and statistical tests (average variances in the matched and mismatched groups were 1.36 and 1.40, respectively). Multivariable competing risk regression analyses were performed for acute GVHD II-IV, acute GVHD III-IV, chronic GVHD, relapse, NRM and CMV reactivation, using an extended Fine and Gray model ${ }^{45-47}$. For OS and RFS, Cox proportional regression models were used ${ }^{48}$. Competing events were defined as death without GVHD and relapse for GVHD endpoints (acute and chronic GVHD); death from any cause other than transplantation for NRM; relapse and death for CMV reactivation; and non-relapse mortality for relapse. All statistical models were adjusted for center effect and covariates defining the European Society for Blood and Marrow Transplantation risk score: patient age, disease stage at transplantation, time to transplantation, and donor-recipient sex combination. In addition to these, the following relevant variables were included: HLA-DPB1 matching (T-cell epitope matching level as defined by Fleischhauer et al. $^{49}$ ), patient-donor serological status for cytomegalovirus, year of transplantation, source of stem cells, conditioning regimen, GVHD prophylaxis, treatment with antithymocyte globulin or Alemtuzumab, and disease category. Interactions between patient-donor serological status for cytomegalovirus and matching at amino acid position 98 of $M I C B$ were also assessed in the multivariable analyses. ${ }^{50,51} \mathrm{All}$ models were checked for interactions and proportional hazards assumptions. All statistical analyses were conducted using the computing environment $R^{52}$. 


\section{RESULTS}

The demographics of the study population are shown in Table 1. The median post-transplant follow-up was 36 months (mean: 37 months; range: 1 to 105 months), and the median patient age was 53 years (mean: 48 years; range: 1 to 73 years). The patients suffered from both malignant and non-malignant diseases. Most transplants were performed with non-myeloablative/reduced intensity conditioning regimens $(67 \%)$; in vivo T-cell depletion was performed in the majority of cases (73\%), and peripheral blood was the main source for stem cells $(79 \%)$. All donor/patient pairs were fully typed at high resolution $\left(2^{\text {nd }}\right.$ field $)$ for $H L A-A,-B,-C$, $D R B 1,-D Q B 1,-D P B 1$ and $M I C A^{29}$ and were matched for 12 out of 12 alleles at $H L A-$ $A,-B,-C,-D R B 1,-D Q B 1$ and MICA loci. Among the 943 transplantations, 394 (41.8\%) had non-permissive HLA-DPB1 mismatches. Fifty-six (5.9\%) transplants were MICB98 mismatched. The mismatch vectors of these 56 transplants were graftversus-host $(n=22)$, host-versus-graft $(n=33)$ and bidirectional $(n=1)$. Except for the patient-donor CMV status, all relevant covariates for the analyzed clinical outcomes were equally distributed in the MICB98 matched and -mismatched patients (Table 1).

Organ-specific sub-analyses showed that the MICB98 matching effect was more important in the gut and the skin than in the liver (supplemental Figure 1). MICB98 mismatches were significantly associated with an increased incidence of acute GVHD (hazard ratio (HR) for grades II-IV: $1.20 ; 95 \% \mathrm{Cl}, 1.15$ to $1.24 ; P<0.001$; for grades III-IV: $2.28 ; 95 \% \mathrm{Cl}, 1.56$ to $3.34 ; P<0.001$ ) (Table 2). At day 100 post-HCT, the cumulative incidences of severe (grades III-IV) acute GVHD in MICB98 mismatched vs. matched transplantations were $18.9 \%$ vs. $12.5 \%$, respectively

(Figure 1A). Matching MICB at position 98 decreased the risk of chronic GVHD by 
$4 \%(40.9 \%$ vs. $36.9 \%)$ at 4 years post-transplantation (HR, $1.21 ; 95 \% \mathrm{Cl}, 1.10$ to 1.33; $P<0.001$ ) (Table 2 and Figure 1B). In addition, MICB98 mismatches were associated with a higher rate of relapse $(\mathrm{HR}, 1.42 ; 95 \% \mathrm{Cl}, 1.05$ to $1.93 ; P=0.024)$.

Knowing that amino acid position 98 is involved in the binding of MICB to the UL16 protein of the CMV, we assessed the interaction between MICB98 mismatches and the CMV status in their effect on clinical outcomes. For this purpose, we performed multivariate analyses and included an interaction factor in the model. Table 3 represents the risks of various clinical outcomes associated with (1) MICB98 mismatches when donor and recipients are negative for CMV, (2) CMV positivity in donor and/or recipients when MICB98 is matched and (3) the interaction of MICB98 matching with CMV status. A statistically significant value for the interaction factor indicates that the effect of MICB98 matching depends on the category of CMV status and vice versa. When the hazard ratio of the interaction factor is $<1$ or $>1$, the hazard ratio of a variable (here, MICB98 matching or CMV status) is, respectively, lower or higher in the category at risk of its interacting variable compared to the reference category. For example, when the hazard ratio of the interaction factor is < 1, the hazard ratio of MICB98 mismatches is lower when the donor and/or recipient are positive for CMV (category at risk of the CMV status variable) and higher when both the donor and recipient are negative for CMV (reference category of the CMV status variable).

For acute GVHD III-IV, the hazard ratio of the interaction was $<1$ and was statistically significant (hazard ratio for acute GVHD III-IV, $0.26 ; 95 \% \mathrm{Cl}, 0.17$ to 0.40 ; $P<0.001$ ), indicating that the effect of MICB98 mismatching on acute GVHD is more important when both the donor and the recipient are negative for CMV (acute GVHD III-IV hazard ratio, $3.63 ; 95 \% \mathrm{Cl}, 3.15$ to $4.18 ; \mathrm{P}<0.001$ ) compared to when the donor 
and/or the recipient are positive for CMV (acute GVHD III-IV hazard ratio, $3.63 \times 0.26$ $=0.94)$. This observation was confirmed by representing graphically cumulative incidences of acute GVHD III-IV in the above mentioned two CMV subgroups (Figure $2 \mathrm{~A}$ and $2 \mathrm{~B})$.

For OS, the interaction between MICB98 mismatching and CMV status was statistically significant and was $>1$ (hazard ratio, $1.53 ; 95 \% \mathrm{Cl}, 1.38$ to $1.69 ; \mathrm{P}<$ 0.001). CMV positivity in the donor and/or recipient was associated with a slightly lower survival when MICB98 was matched (hazard ratio, 1.16 ; $95 \% \mathrm{Cl}, 1.14$ to 1.19 ; $\mathrm{P}<0.001)$. However, because of the positive interaction with MICB98 mismatches, this effect was higher when MICB98 was mismatched (hazard ratio $1.16 \times 1.53=$ 1.77) (Table 3). The Kaplan-Meier estimates showing the higher impact of the CMV status on OS in MICB98 matched and mismatched groups are presented in Figures $2 \mathrm{C}$ and $2 \mathrm{D}$, respectively. In other words, the risk of death associated with CMV positivity in the donor and/or recipient is lower in MICB98 matched vs. mismatched groups.

Finally, to assess whether MICB98 mismatches had a GVHD-independent effect on CMV infections in donor/recipients pairs at risk for CMV reactivation (i.e., the donor and/or recipient was positive for $\mathrm{CMV}$ pre-HCT), we performed a multivariate Fine and Gray analysis that included MICB98 matching as well as the presence/absence of acute GVHD grades III-IV and chronic GVHD as timedependent covariates in the model (Table 4). In accordance with the higher risk of death described above, MICB98 mismatches were associated with a higher incidence of CMV infections (hazard ratio, $1.84 ; 95 \% \mathrm{Cl}, 1.34$ to $2.51 ; P<0.001$ ) (Table 4 and Figure 3). MICB98 mismatches were not associated with EBV or HHV6 infections (Supplemental Table 1). 


\section{DISCUSSION}

This is the first study analyzing the role of $M I C B$ matching in transplantation (whether HCT or solid organ).

Here we report that HCT from a MICB98 mismatched, but otherwise fully HLA 10/10 and MICA matched donor, carries a significantly increased risk of acute and chronic GVHD. Interestingly, the effect on GVHD was not accompanied by a decreased relapse rate. This unusual observation may be attributed to the CMV status that is not independent of the MICB98 matching status. The significant interaction of MICB98 matching with CMV status $(P<0.001)$ indicates that the CMV status has a strong positive impact on relapse when MICB98 is mismatched $(\mathrm{HR}$, $0.77 \times 2.61=2.01)($ Table 3$)$

CMV biology has been known to be linked to MICB for more than 15 years. Initially, Cosman et al. demonstrated that CMV infected cells can evade the immune system by the retention of MICB and ULBP-1 and -2 antigens in the cell via binding to the CMV protein UL $16^{36}$. This interaction hampers the ability of newly synthesized MICB proteins to mature and transit the secretory pathway ${ }^{53}$. By dissecting the molecular basis of MICB binding to UL16, Spreu et al. reported that the UL16-MICB interaction is dependent on helical structures of the MICB $\alpha 2$ domain ${ }^{54}$. Finally, more recently, it was shown that UL16 binding was not equivalent for all MICB alleles. The $M I C B^{\star} 008$ allele in particular was shown to have a decreased binding activity compared to other alleles that do not have a methionine at position 98 in the MICB $\alpha 2$ domain ${ }^{37}$. Importantly, position 98 is the only polymorphic position of MICB that is known to be in direct contact with UL16 ${ }^{38}$. It is therefore not surprising that mismatches at this position have less impact on acute GVHD in the presence of CMV 
than in its absence. In the absence of CMV, the MICB98 polymorphism may indeed not be able to modulate the expression of MICB at the cell surface through interaction with UL16 and consequently is not able to influence the alloreactivity that remains higher in the mismatch than in the matched situation. Another explanation for the higher MICB-mediated alloreactivity in the absence of CMV may be the absence of Tcell exhaustion, that is known to be induced by CMV positivity ${ }^{55}$. Ultimately, this observation demonstrates that to lower the risk of acute GVHD in the absence of CMV (donor and recipient seronegative), a MICB98 matched donor is a better choice than a MICB98 mismatched donor.

CMV causes mortality in two ways: (1) directly by causing viral diseases, such as pneumonitis, a situation that is becoming rare (viral diseases represent less than $2 \%$ of deaths) thanks to preemptive therapies, or (2) indirectly by clinical events associated with virus seropositivity or the development of viral infections that are independent of the viral disease itself ${ }^{56}$. The indirect effects of CMV are recognized as a major cause of adverse outcomes after HCT, including GVHD and overall mortality ${ }^{56-58}$. Our dataset showed that the CMV effect on overall survival is amplified in MICB98 mismatched HCT compared to MICB98 matched HCT, indicating that matching donors at this position could be a useful strategy to decrease the risk of death related to CMV. Because MICB98 mismatches were further shown to be associated with CMV infection episodes, and this independently of the occurrence of GVHD, deaths related to CMV may be due to CMV infections.

Collectively, these results suggest that pre-transplantation MICB98 typing may help in lowering the risk of both GVHD- and CMV-related mortality. In the absence of CMV, matching MICB98 provides a means to lower the incidence of GVHD, whereas in the presence of CMV, it helps improve overall survival. Fortunately, the level of 
MICB98 mismatching is only $5.9 \%$ in HLA 10/10 matched donor/patient pairs that are also matched for MICA; although in absolute terms, this represents several thousand patients per year. Therefore, finding a MICB98-matched donor should be relatively easy in clinical practice.

\section{ACKNOWLEDGMENTS}

We would like to thank Prof. Robert Zeiser (University of Freiburg/Germany) for critical reading of this manuscript. We thank Martin Verniquet for critical review of statistical analyses. We would also like to thank Nicole Raus (SFGM-TC, Lyon, France) for retrieving the clinical data from the ProMISe database. This work was supported by grants from the Agence Nationale de la Recherche (ANR) (ANR-11-LABX0070_TRANSPLANTEX), and the INSERM (UMR_S 1109), the Institut Universitaire de France (IUF), all to SB; from the University of Strasbourg (IDEX UNISTRA) to CP and SB; from the European regional development fund (European Union) INTERREG $\vee$ program (project n`3.2 TRIDIAG) to RC and SB; and from MSD-Avenir grant AUTOGEN to SB.

\section{AUTHOR CONTRIBUTIONS}

$\mathrm{RC}$ performed the experiments, designed the study, analyzed the data and wrote the manuscript. SB designed the study, analyzed the data and wrote the manuscript. PS, $\mathrm{AM}, \mathrm{IK}, \mathrm{CM}, \mathrm{APi}$ and VR performed the experiments and analyzed the data. IA performed the statistics. PAvdB, DB, AC, DC, FCl, KG, JK, JJ, MLaba, PL, MMi, NM, PM, MOu, APa, RP, CPi, GS, ES, RT, AT, IY and BvdH provided samples and clinical data, interpreted the clinical data and discussed the results. BL, MMo, AN and $\mathrm{CPa}$ interpreted the clinical data and discussed results. FB, YK, MMB, MOt, and 
$\mathrm{BvdH}$ analyzed the data and reviewed statistics. All authors contributed to the writing of the report and approved the final version of the manuscript.

\section{Ethics declarations}

\section{Conflict of interest}

$\mathrm{SB}$ is the scientific founder and a (minority) shareholder of BIOMICA SAS. JK is the co-founder and chief scientific officer of Gadeta. He received personal fees from Gadeta. In addition, JK has a patent issued/pending. ES is the inventor of a patent application filed by the University Medical Center Utrecht on the prediction of an alloimmune response against mismatched HLA (PCT/EPT2013/073386). All other authors declare no competing interests.

\section{REFERENCES}

1. Forman JS, Negrin SR, Antin HJ, Appelbaum RF. Thomas' Hematopoietic Cell Transplantation, Fifth Edition, 2016.

2. Appelbaum FR, Thomas ED. Thomas' hematopoietic cell transplantation : stem cell transplantation, 4th edn Wiley-Blackwell: Chichester, UK ; Hoboken, NJ, 2009.

3. Gratwohl A, Baldomero H, Aljurf M, Pasquini MC, Bouzas LF, Yoshimi A et al. Hematopoietic stem cell transplantation: a global perspective. JAMA : the journal of the American Medical Association 2010; 303(16): 1617-1624. e-pub ahead of print 2010/04/29; doi: 10.1001/jama.2010.491

4. D'Souza A, Fretham C. Current Uses and Outcomes of Hematopoietic Cell Transplantation (HCT): CIBMTR Summary Slides, 2018. (Accessed April 2019 at https://www.cibmtr.org) 2018.

5. Gooley TA, Chien JW, Pergam SA, Hingorani S, Sorror ML, Boeckh M et al. Reduced mortality after allogeneic hematopoietic-cell transplantation. The New England journal of medicine 2010; 363(22): 2091-2101. e-pub ahead of print 2010/11/26; doi: 10.1056/NEJMoa1004383

6. Warren EH, Zhang XC, Li S, Fan W, Storer BE, Chien JW et al. Effect of MHC and non-MHC donor/recipient genetic disparity on the outcome of allogeneic HCT. Blood 2012; 120(14): 2796-2806. e-pub ahead of print 2012/08/04; doi: 10.1182/blood-2012-04-347286 
7. Mori T, Kato J. Cytomegalovirus infection/disease after hematopoietic stem cell transplantation. International journal of hematology 2010; 91(4): 588-595. e-pub ahead of print 2010/04/24; doi: 10.1007/s12185-010-0569-x

8. Paris C, Kopp K, King A, Santolaya ME, Zepeda AJ, Palma J. Cytomegalovirus infection in children undergoing hematopoietic stem cell transplantation in Chile. Pediatric blood \& cancer 2009; 53(3): 453-458. e-pub ahead of print 2009/05/07; doi: 10.1002/pbc.22060

9. Boeckh M, Nichols WG, Papanicolaou G, Rubin R, Wingard JR, Zaia J. Cytomegalovirus in hematopoietic stem cell transplant recipients: Current status, known challenges, and future strategies. Biology of blood and marrow transplantation : journal of the American Society for Blood and Marrow Transplantation 2003; 9(9): 543-558. e-pub ahead of print 2003/09/25;

10. Boeckh $M$, Ljungman P. How we treat cytomegalovirus in hematopoietic cell transplant recipients. Blood 2009; 113(23): 5711-5719. e-pub ahead of print 2009/03/21; doi: 10.1182/blood-2008-10-143560

11. Ljungman P, Griffiths P, Paya C. Definitions of cytomegalovirus infection and disease in transplant recipients. Clinical infectious diseases : an official publication of the Infectious Diseases Society of America 2002; 34(8): 1094-1097. e-pub ahead of print 2002/03/27; doi: $10.1086 / 339329$

12. Ljungman $\mathrm{P}$, Hakki $\mathrm{M}$, Boeckh $\mathrm{M}$. Cytomegalovirus in hematopoietic stem cell transplant recipients. Hematology/oncology clinics of North America 2011; 25(1): 151-169. e-pub ahead of print 2011/01/18; doi: 10.1016/j.hoc.2010.11.011

13. Takenaka K, Nishida T, Asano-Mori Y, Oshima K, Ohashi K, Mori T et al. Cytomegalovirus Reactivation after Allogeneic Hematopoietic Stem Cell Transplantation is Associated with a Reduced Risk of Relapse in Patients with Acute Myeloid Leukemia Who Survived to Day 100 after Transplantation: The Japan Society for Hematopoietic Cell Transplantation Transplantation-related Complication Working Group. Biology of blood and marrow transplantation : journal of the American Society for Blood and Marrow Transplantation 2015; 21(11): 2008-2016. e-pub ahead of print 2015/07/28; doi: 10.1016/j.bbmt.2015.07.019

14. Manjappa S, Bhamidipati PK, Stokerl-Goldstein KE, DiPersio JF, Uy GL, Westervelt P et al. Protective effect of cytomegalovirus reactivation on relapse after allogeneic hematopoietic cell transplantation in acute myeloid leukemia patients is influenced by conditioning regimen. Biology of blood and marrow transplantation : journal of the American Society for Blood and Marrow Transplantation 2014; 20(1): 46-52. e-pub ahead of print 2013/10/15; doi: 10.1016/j.bbmt.2013.10.003

15. Jang JE, Kim SJ, Cheong JW, Hyun SY, Kim YD, Kim YR et al. Early CMV replication and subsequent chronic GVHD have a significant anti-leukemic effect after allogeneic HSCT in acute myeloid leukemia. Annals of hematology 2015; 94(2): 275-282. e-pub ahead of print 2014/08/20; doi: 10.1007/s00277-014-2190-1 
16. Nichols WG, Corey L, Gooley T, Davis C, Boeckh M. High risk of death due to bacterial and fungal infection among cytomegalovirus (CMV)-seronegative recipients of stem cell transplants from seropositive donors: evidence for indirect effects of primary CMV infection. The Journal of infectious diseases 2002; 185(3): 273-282. e-pub ahead of print 2002/01/25; doi: $10.1086 / 338624$

17. Sousa H, Boutolleau D, Ribeiro J, Teixeira AL, Pinho Vaz C, Campilho F et al. Cytomegalovirus infection in patients who underwent allogeneic hematopoietic stem cell transplantation in Portugal: a five-year retrospective review. Biology of blood and marrow transplantation : journal of the American Society for Blood and Marrow Transplantation 2014; 20(12): 19581967. e-pub ahead of print 2014/08/21; doi: 10.1016/j.bbmt.2014.08.010

18. Ichihara $\mathrm{H}$, Nakamae $\mathrm{H}$, Hirose $\mathrm{A}$, Nakane $\mathrm{T}$, Koh $\mathrm{H}$, Hayashi $\mathrm{Y}$ et al. Immunoglobulin prophylaxis against cytomegalovirus infection in patients at high risk of infection following allogeneic hematopoietic cell transplantation. Transplantation proceedings 2011; 43(10): 3927-3932. e-pub ahead of print 2011/12/17; doi: 10.1016/j.transproceed.2011.08.104

19. Schmidt-Hieber M, Labopin M, Beelen D, Volin L, Ehninger G, Finke J et al. CMV serostatus still has an important prognostic impact in de novo acute leukemia patients after allogeneic stem cell transplantation: a report from the Acute Leukemia Working Party of EBMT. Blood 2013; 122(19): 3359-3364. e-pub ahead of print 2013/09/17; doi: 10.1182/blood-2013-05499830

20. Petersdorf EW. Optimal HLA matching in hematopoietic cell transplantation. Current opinion in immunology 2008; 20(5): 588-593. e-pub ahead of print 2008/08/05; doi: 10.1016/j.coi.2008.06.014

21. Miller W, Flynn P, McCullough J, Balfour HH, Jr., Goldman A, Haake R et al. Cytomegalovirus infection after bone marrow transplantation: an association with acute graft-v-host disease. Blood 1986; 67(4): 1162-1167. e-pub ahead of print 1986/04/01;

22. Flomenberg N, Baxter-Lowe LA, Confer D, Fernandez-Vina M, Filipovich A, Horowitz $M$ et al. Impact of HLA class I and class II high-resolution matching on outcomes of unrelated donor bone marrow transplantation: HLA-C mismatching is associated with a strong adverse effect on transplantation outcome. Blood 2004; 104(7): 1923-1930. e-pub ahead of print 2004/06/12; doi: 10.1182/blood-2004-03-0803

23. Ruell J, Barnes C, Mutton K, Foulkes B, Chang J, Cavet J et al. Active CMV disease does not always correlate with viral load detection. Bone marrow transplantation 2007; 40(1): 55-61. e-pub ahead of print 2007/05/01; doi: 10.1038/sj.bmt.1705671

24. Castagnola E, Cappelli B, Erba D, Rabagliati A, Lanino E, Dini G. Cytomegalovirus infection after bone marrow transplantation in children. Human immunology 2004; 65(5): 416-422. epub ahead of print 2004/06/03; doi: 10.1016/j.humimm.2004.02.013 
25. Bahram S, Bresnahan M, Geraghty DE, Spies T. A second lineage of mammalian major histocompatibility complex class I genes. Proceedings of the National Academy of Sciences of the United States of America 1994; 91(14): 6259-6263. e-pub ahead of print 1994/07/05; doi: 10.1073/pnas.91.14.6259

26. Carapito R, Bahram S. Genetics, genomics, and evolutionary biology of NKG2D ligands. Immunological reviews 2015; 267(1): 88-116. e-pub ahead of print 2015/08/19; doi: 10.1111/imr.12328

27. Bahram S, Spies T. Nucleotide sequence of a human MHC class I MICB CDNA. Immunogenetics 1996; 43(4): 230-233. e-pub ahead of print 1996/01/01;

28. Bahram S, Shiina T, Oka A, Tamiya G, Inoko H. Genomic structure of the human MHC class I MICB gene. Immunogenetics 1996; 45(2): 161-162. e-pub ahead of print 1996/01/01;

29. Carapito R, Jung N, Kwemou M, Untrau M, Michel S, Pichot A et al. Matching for the nonconventional MHC-I MICA gene significantly reduces the incidence of acute and chronic GVHD. Blood 2016; 128(15): 1979-1986. e-pub ahead of print 2016/08/24; doi: 10.1182/blood-2016-05-719070

30. Fuerst D, Neuchel C, Niederwieser D, Bunjes D, Gramatzki M, Wagner E et al. Matching for the MICA-129 polymorphism is beneficial in unrelated hematopoietic stem cell transplantation. Blood 2016; 128(26): 3169-3176. e-pub ahead of print 2016/11/05; doi: 10.1182/blood-2016-05-716357

31. Petersdorf EW, Hansen JA, Martin PJ, Woolfrey A, Malkki M, Gooley T et al. Majorhistocompatibility-complex class I alleles and antigens in hematopoietic-cell transplantation. The New England journal of medicine 2001; 345(25): 1794-1800. e-pub ahead of print 2001/12/26; doi: 10.1056/NEJMoa011826

32. Groh V, Bahram S, Bauer S, Herman A, Beauchamp M, Spies T. Cell stress-regulated human major histocompatibility complex class I gene expressed in gastrointestinal epithelium. Proceedings of the National Academy of Sciences of the United States of America 1996; 93(22): 12445-12450. e-pub ahead of print 1996/10/29;

33. Wang WY, Tian W, Zhu FM, Liu XX, Li LX, Wang F. MICA, MICB Polymorphisms and Linkage Disequilibrium with HLA-B in a Chinese Mongolian Population. Scandinavian journal of immunology 2016; 83(6): 456-462. e-pub ahead of print 2016/03/31; doi: 10.1111/sji.12437

34. Liu X, Tian W, Li L, Cai J. Characterization of the major histocompatibility complex class I chain-related gene $B(\mathrm{MICB})$ polymorphism in a northern Chinese Han population: the identification of a new MICB allele, MICB*023. Human immunology 2011; 72(9): 727-732. epub ahead of print 2011/06/15; doi: 10.1016/j.humimm.2011.05.013 
35. Lanier LL. Up on the tightrope: natural killer cell activation and inhibition. Nature immunology 2008; 9(5): 495-502. e-pub ahead of print 2008/04/22; doi: 10.1038/ni1581

36. Cosman D, Mullberg J, Sutherland CL, Chin W, Armitage R, Fanslow W et al. ULBPs, novel MHC class I-related molecules, bind to CMV glycoprotein UL16 and stimulate NK cytotoxicity through the NKG2D receptor. Immunity 2001; 14(2): 123-133. e-pub ahead of print 2001/03/10;

37. Klumkrathok K, Jumnainsong A, Leelayuwat C. Allelic MHC class I chain related B (MICB) molecules affect the binding to the human cytomegalovirus (HCMV) unique long 16 (UL16) protein: implications for immune surveillance. Journal of microbiology 2013; 51(2): 241-246. e-pub ahead of print 2013/04/30; doi: 10.1007/s12275-013-2514-1

38. Muller S, Zocher G, Steinle A, Stehle T. Structure of the HCMV UL16-MICB complex elucidates select binding of a viral immunoevasin to diverse NKG2D ligands. PLoS pathogens 2010; 6(1): e1000723. e-pub ahead of print 2010/01/22; doi: 10.1371/journal.ppat.1000723

39. Hill GR, Ferrara JL. The primacy of the gastrointestinal tract as a target organ of acute graftversus-host disease: rationale for the use of cytokine shields in allogeneic bone marrow transplantation. Blood 2000; 95(9): 2754-2759. e-pub ahead of print 2000/04/26;

40. Isernhagen A, Malzahn D, Viktorova E, Elsner L, Monecke S, von Bonin F et al. The MICA-129 dimorphism affects NKG2D signaling and outcome of hematopoietic stem cell transplantation. EMBO molecular medicine 2015; 7(11): 1480-1502. e-pub ahead of print 2015/10/21; doi: 10.15252/emmm.201505246

41. Boukouaci W, Busson M, Peffault de Latour R, Rocha V, Suberbielle C, Bengoufa D et al. MICA-129 genotype, soluble MICA, and anti-MICA antibodies as biomarkers of chronic graftversus-host disease. Blood 2009; 114(25): 5216-5224. e-pub ahead of print 2009/09/30; doi: 10.1182/blood-2009-04-217430

42. Parmar S, Del Lima M, Zou Y, Patah PA, Liu P, Cano P et al. Donor-recipient mismatches in $\mathrm{MHC}$ class I chain-related gene $\mathrm{A}$ in unrelated donor transplantation lead to increased incidence of acute graft-versus-host disease. Blood 2009; 114(14): 2884-2887. e-pub ahead of print 2009/08/06; doi: 10.1182/blood-2009-05-223172

43. Pellet $\mathrm{P}$, Renaud $\mathrm{M}$, Fodil $\mathrm{N}$, Laloux $\mathrm{L}$, Inoko $\mathrm{H}$, Hauptmann $\mathrm{G}$ et al. Allelic repertoire of the human MICB gene. Immunogenetics 1997; 46(5): 434-436. e-pub ahead of print 1997/09/01;

44. Glucksberg H, Storb R, Fefer A, Buckner CD, Neiman PE, Clift RA et al. Clinical manifestations of graft-versus-host disease in human recipients of marrow from HL-A-matched sibling donors. Transplantation 1974; 18(4): 295-304. e-pub ahead of print 1974/10/01; doi: 10.1097/00007890-197410000-00001 
45. Scheike $\mathrm{TH}$, Zhang MJ. Analyzing Competing Risk Data Using the R timereg Package. Journal of statistical software 2011; 38(2). e-pub ahead of print 2011/01/01;

46. Scheike TH, Zhang MJ. Flexible competing risks regression modeling and goodness-of-fit. Lifetime data analysis 2008; 14(4): 464-483. e-pub ahead of print 2008/08/30; doi: 10.1007/s10985-008-9094-0

47. Scheike $\mathrm{T}$, Zhang $\mathrm{M}$, Gerds $\mathrm{T}$. Predicting cumulative incidence probability by direct binomial regression. Biometrika 2008; 95(1): 205-220.

48. Therneau T, Grambsch P. Modeling Survival Data: Extending the Cox Model. Springer 2000.

49. Fleischhauer K, Shaw BE, Gooley T, Malkki M, Bardy P, Bignon JD et al. Effect of T-cell-epitope matching at HLA-DPB1 in recipients of unrelated-donor haemopoietic-cell transplantation: a retrospective study. The Lancet. Oncology 2012; 13(4): 366-374. e-pub ahead of print 2012/02/22; doi: 10.1016/S1470-2045(12)70004-9

50. Peduzzi P, Concato J, Feinstein AR, Holford TR. Importance of events per independent variable in proportional hazards regression analysis. II. Accuracy and precision of regression estimates. Journal of clinical epidemiology 1995; 48(12): 1503-1510. e-pub ahead of print 1995/12/01; doi: 10.1016/0895-4356(95)00048-8

51. Peduzzi P, Concato J, Kemper E, Holford TR, Feinstein AR. A simulation study of the number of events per variable in logistic regression analysis. Journal of clinical epidemiology 1996; 49(12): 1373-1379. e-pub ahead of print 1996/12/01; doi: 10.1016/s0895-4356(96)00236-3

52. Team RDC. R: A language and environment for statistical computing. In: Vienna, Austria: R Foundation for Statistical Computing., 2010. pp Retrieved from http://R-project.org.

53. Wu J, Chalupny NJ, Manley TJ, Riddell SR, Cosman D, Spies T. Intracellular retention of the MHC class I-related chain B ligand of NKG2D by the human cytomegalovirus UL16 glycoprotein. Journal of immunology 2003; 170(8): 4196-4200. e-pub ahead of print 2003/04/12;

54. Spreu J, Stehle T, Steinle A. Human cytomegalovirus-encoded UL16 discriminates MIC molecules by their alpha2 domains. Journal of immunology 2006; 177(5): 3143-3149. e-pub ahead of print 2006/08/22;

55. Nikolich-Zugich J, Goodrum F, Knox K, Smithey MJ. Known unknowns: how might the persistent herpesvirome shape immunity and aging? Current opinion in immunology 2017; 48: 23-30. e-pub ahead of print 2017/08/07; doi: 10.1016/j.coi.2017.07.011 
664

665

666

667
56. de la Camara R. CMV in Hematopoietic Stem Cell Transplantation. Mediterranean journal of hematology and infectious diseases 2016; 8(1): e2016031. e-pub ahead of print 2016/07/15; doi: 10.4084/MJHID.2016.031

57. Broers AE, van Der Holt R, van Esser JW, Gratama JW, Henzen-Logmans S, KuenenBoumeester $\mathrm{V}$ et al. Increased transplant-related morbidity and mortality in CMVseropositive patients despite highly effective prevention of CMV disease after allogeneic Tcell-depleted stem cell transplantation. Blood 2000; 95(7): 2240-2245. e-pub ahead of print 2000/03/25;

58. Cantoni N, Hirsch HH, Khanna N, Gerull S, Buser A, Bucher C et al. Evidence for a bidirectional relationship between cytomegalovirus replication and acute graft-versus-host disease. Biology of blood and marrow transplantation : journal of the American Society for Blood and Marrow Transplantation 2010; 16(9): 1309-1314. e-pub ahead of print 2010/04/01; doi: 10.1016/j.bbmt.2010.03.020 


\section{FIGURE LEGENDS}

669

Figure 1. Effect of MICB98 matching on severe acute and chronic GVHD

671 The cumulative incidences of grades III-IV acute (panel A) and chronic GVHD (Panel

672 B) are shown for MICB98 mismatched (1) versus matched (2) patients.

673

674 Figure 2. Effect of MICB98 matching and CMV status on GVHD and Overall 675 Survival.

676 Panels A and B represent the cumulative incidences of grades III-IV acute GVHD in 677 HCT with donors and recipients negative for $\mathrm{CMV}(\mathrm{A})$ and HCT with donors and/or 678 recipients positive for CMV (B). Panels $C$ and D show the Kaplan-Meier estimates of 679 overall survival in MICB98 matched (C) and mismatched (D) transplants.

680

681

Figure 3. Effect of MICB98 matching on CMV reactivation/infection

682 The cumulative incidences of post-transplant CMV infection episodes in MICB98 683 mismatched (1) versus matched (2) patients are shown. 


\begin{tabular}{|c|c|c|c|c|}
\hline & $\begin{array}{l}\text { Total transplants } \\
(n=943)\end{array}$ & $\begin{array}{c}\text { MICB } 98 \\
\text { matched } \\
\text { transplants } \\
(n=887) \\
\end{array}$ & $\begin{array}{c}\text { MICB } 98 \\
\text { mismatched } \\
\text { transplants } \\
(n=56)\end{array}$ & P-value* \\
\hline $\begin{array}{c}\text { Transplantation centers } † \\
1 \\
2 \\
3 \\
4 \\
5 \\
6 \\
7 \\
8 \\
9\end{array}$ & $\begin{array}{c}106(11.2 \%) \\
158(16.8 \%) \\
114(12.1 \%) \\
157(16.6 \%) \\
48(5.1 \%) \\
99(10.5 \%) \\
96(10.2 \%) \\
49(5.2 \%) \\
116(12.3 \%)\end{array}$ & $\begin{array}{c}100(11.3 \%) \\
142(16 \%) \\
109(12.3 \%) \\
153(17.2 \%) \\
47(5.3 \%) \\
90(10.1 \%) \\
91(10.3 \%) \\
46(5.2 \%) \\
109(12.3 \%)\end{array}$ & $\begin{array}{c}6(10.7 \%) \\
16(28.6 \%) \\
5(8.9 \%) \\
4(7.1 \%) \\
1(1.8 \%) \\
9(16.1 \%) \\
5(8.9 \%) \\
3(5.4 \%) \\
7(12.5 \%)\end{array}$ & 0.16 \\
\hline $\begin{array}{l}\text { Age at transplant (years) } \\
\begin{array}{l}0-17 \\
18-49 \\
50-64 \\
65 \text { or older }\end{array}\end{array}$ & $\begin{array}{c}58(6.2 \%) \\
360(38.2 \%) \\
458(48.6 \%) \\
67(7.1 \%)\end{array}$ & $\begin{array}{c}57(6.4 \%) \\
333(37.5 \%) \\
430(48.5 \%) \\
67(7.6 \%)\end{array}$ & $\begin{array}{c}1(1.8 \%) \\
27(48.2 \%) \\
28(50 \%) \\
0(0 \%)\end{array}$ & 0.034 \\
\hline $\begin{array}{l}\text { Year of transplantation } \\
\text { 2005-2008 } \\
2009-2013\end{array}$ & $\begin{array}{l}360(38.2 \%) \\
583(61.8 \%)\end{array}$ & $\begin{array}{l}338(38.1 \%) \\
549(61.9 \%)\end{array}$ & $\begin{array}{l}22(39.3 \%) \\
34(60.7 \%)\end{array}$ & 0.97 \\
\hline $\begin{array}{l}\text { Patient-donor sex } \\
\text { Male-Female } \\
\text { Other combinations } \\
\text { Missing }\end{array}$ & $\begin{array}{c}159(16.9 \%) \\
779(82.6 \%) \\
5(0.5 \%)\end{array}$ & $\begin{array}{c}150(16.9 \%) \\
732(82.5 \%) \\
5(0.6 \%)\end{array}$ & $\begin{array}{c}9(16.1 \%) \\
47(83.9 \%) \\
0(0 \%)\end{array}$ & 1.00 \\
\hline $\begin{array}{l}\text { Patient-donor CMV status } \\
\text { neg.-neg. } \\
\text { pos.-neg./neg.-pos./pos.-pos. } \\
\text { Missing }\end{array}$ & $\begin{array}{c}357(37.9 \%) \\
560(59.4 \%) \\
26(2.7 \%)\end{array}$ & $\begin{array}{c}329(37.1 \%) \\
533(60.1 \%) \\
25(2.8 \%)\end{array}$ & $\begin{array}{c}28(50 \%) \\
27(48.2 \%) \\
1(1.8 \%)\end{array}$ & 0.082 \\
\hline $\begin{array}{l}\text { Source of cells } \\
\text { Bone marrow } \\
\text { Peripheral blood stem cells }\end{array}$ & $\begin{array}{l}195(20.7 \%) \\
748(79.3 \%)\end{array}$ & $\begin{array}{l}183(20.6 \%) \\
704(79.4 \%)\end{array}$ & $\begin{array}{l}12(21.4 \%) \\
44(78.6 \%)\end{array}$ & 1.00 \\
\hline $\begin{array}{l}\text { Conditioning regimen } \\
\text { Non-myeloablative/reduced-intensity } \\
\text { Myeloablative without total-body irradiation } \\
\text { Myeloablative with total-body irradiation } \\
\text { Missing }\end{array}$ & $\begin{array}{c}635(67.3 \%) \\
140(14.8 \%) \\
167(17.7 \%) \\
1(0.1 \%)\end{array}$ & $\begin{array}{c}598(67.4 \%) \\
130(14.7 \%) \\
158(17.8 \%) \\
1(0.1 \%)\end{array}$ & $\begin{array}{c}37(66.1 \%) \\
10(17.9 \%) \\
9(16.1 \%) \\
0(0 \%)\end{array}$ & 0.79 \\
\hline $\begin{array}{l}\text { GvHD prophylaxis } \\
\text { Cyclosporin only } \\
\text { Cyclosporin and Methotrexate } \\
\text { Cyclosporin and Mycophenolate } \\
\text { Other combinations } \\
\text { Missing }\end{array}$ & $\begin{array}{c}183(19.4 \%) \\
243(25.8 \%) \\
360(38.2 \%) \\
135(14.3 \%) \\
22(2.3 \%)\end{array}$ & $\begin{array}{l}171(19.3 \%) \\
231(26 \%) \\
335(37.8 \%) \\
130(14.7 \%) \\
20(2.2 \%)\end{array}$ & $\begin{aligned} 12 & (21.4 \%) \\
12 & (21.4 \%) \\
25 & (44.6 \%) \\
5 & (8.9 \%) \\
2 & (3.6 \%)\end{aligned}$ & 0.49 \\
\hline $\begin{array}{l}\text { In vivo T-cell depletion } \ddagger \\
\text { No } \\
\text { Yes } \\
\text { Missing }\end{array}$ & $\begin{array}{c}231(24.5 \%) \\
690(73.2 \%) \\
22(2.3 \%)\end{array}$ & $\begin{array}{c}214(24.1 \%) \\
653(73.6 \%) \\
20(2.3 \%)\end{array}$ & $\begin{aligned} 17 & (30.3 \%) \\
37 & (66.1 \%) \\
2 & (3.6 \%)\end{aligned}$ & 0.34 \\
\hline $\begin{array}{l}\text { Disease } \\
\text { Acute myeloid leukemia } \\
\text { Chronic myeloid leukemia } \\
\text { Acute lymphoblastic leukemia } \\
\text { Myelodysplastic syndrome } \\
\text { Non-Hodgkin lymphoma } \\
\text { Others } \S\end{array}$ & $\begin{aligned} & 240(25.5 \%) \\
& 34(3.6 \%) \\
& 121(12.8 \%) \\
& 161(17.1 \%) \\
& 127(13.5 \%) \\
& 260(27.6 \%)\end{aligned}$ & $\begin{array}{l}225(25.4 \%) \\
32(3.6 \%) \\
114(12.9 \%) \\
152(17.1 \%) \\
121(13.6 \%) \\
243(27.4 \%)\end{array}$ & $\begin{array}{c}15(26.8 \%) \\
2(3.6 \%) \\
7(12.5 \%) \\
9(16.1 \%) \\
6(10.7 \%) \\
17(30.4 \%)\end{array}$ & 0.99 \\
\hline $\begin{array}{l}\text { Disease stage at transplantation } \mathbb{} \\
\text { Early } \\
\text { Late } \\
\text { Not applicablell } \\
\text { Missing }\end{array}$ & $\begin{array}{c}371(39.3 \%) \\
507(53.8 \%) \\
44(4.7 \%) \\
21(2.2 \%)\end{array}$ & $\begin{array}{c}348(39.2 \%) \\
477(53.8 \%) \\
42(4.7 \%) \\
20(2.3 \%)\end{array}$ & $\begin{array}{c}23(41.1 \%) \\
30(53.6 \%) \\
2(3.6 \%) \\
1(1.8 \%)\end{array}$ & 0.97 \\
\hline $\begin{array}{l}\text { Time until treatment } \\
\quad<12 \text { months } \\
>12 \text { months }\end{array}$ & $\begin{array}{l}440(46.7 \%) \\
503(53.3 \%)\end{array}$ & $\begin{array}{l}416(46.9 \%) \\
471(53.1 \%)\end{array}$ & $\begin{array}{l}24(42.9 \%) \\
32(57.1 \%)\end{array}$ & 0.65 \\
\hline $\begin{array}{l}\text { Non-Permissive HLA-DPB1 matching }{ }^{* *} \\
\text { Matched } \\
\text { Mismatched } \\
\text { Missing }\end{array}$ & $\begin{array}{l}420(44.5 \%) \\
394(41.8 \%) \\
129(13.7 \%)\end{array}$ & $\begin{array}{l}392(44.2 \%) \\
374(42.2 \%) \\
121(13.6 \%)\end{array}$ & $\begin{array}{c}28(50 \%) \\
20(35.7 \%) \\
8(14.3 \%)\end{array}$ & 0.42 \\
\hline
\end{tabular}


688 The results are presented as the number of patients and corresponding percentages of the 689 study population. HLA: Human Leukocyte Antigen. All clinical variables of the table were 690 used for adjustment in the multivariate models.

$691 * P$-values were determined with Pearson's Chi square test or Fisher's exact test for small 692 sample sizes

$693+$ Patients received their transplant in six centers of the Francophone Society of Bone 694 Marrow Transplantation and Cell Therapies (SFGM-TC) (1 to 6; $N=682$ ) and in three Dutch 695 centers that are part of the Europdonor operated by the Matchis Foundation network (7 to 9; $696 \quad \mathrm{~N}=261)$.

$697 \ddagger$ in vivo T-cell depletion was performed by the addition of anti-thymocyte globulin (ATG) or 698 Alemtuzumab to the conditioning regimen.

$699 \S$ Other diseases include multiple myeloma, Hodgkin lymphoma, Fanconi anemia, aplastic 700 anemia, chronic lymphocytic leukemia, plasma cell leukemia, other acute leukemias, solid 701 tumors (not breast), hemophagocytosis and inherited disorders.

702 I Early corresponds to diseases in the first complete remission or in the chronic phase. Late 703 corresponds to second or higher complete remissions, accelerated phases, partial 704 remissions, progressions, primary induction failures, relapses or stable diseases. Not 705 applicable corresponds to bone marrow failure (aplastic anemia, Fanconi anemia), inherited 706 disorders, hemophagocytosis and solid tumors.

$707{ }^{* *} H L A-D P B 1$ matching was defined at the T-cell-epitope matching level ${ }^{49}$ with typing data at $7082^{\text {nd }}$ field resolution following the World Health Organization official nomenclature . 


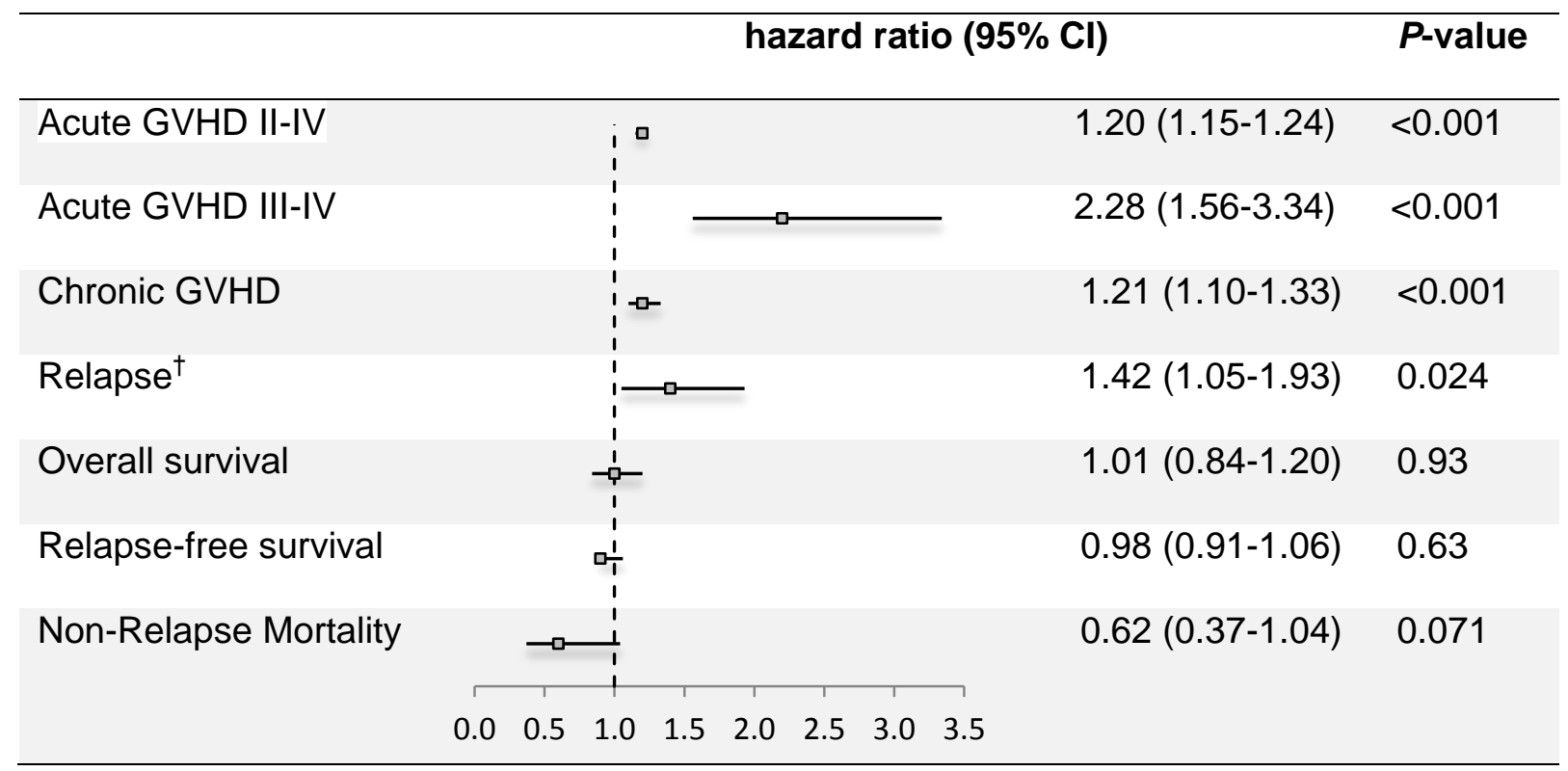

Results are presented as Hazard Ratios with 95\% confidence intervals (Cl). GVHD: Graftversus-host disease. * All models were adjusted for patient's age, patient-donor sex, patientdonor serological status for cytomegalovirus, year of transplantation, time to transplantation, transplantation center, source of stem cells, conditioning regimen, GVHD prophylaxis, treatment with anti-thymocyte globulin or Alemtuzumab, HLA-DPB1 matching status, disease category and severity at transplantation. † Transplantations performed for non-malignant diseases were excluded from the analysis. 


\begin{tabular}{|c|c|c|}
\hline Outcomes and risk factors & hazard ratio $(95 \% \mathrm{Cl})$ & $P$-value \\
\hline \multicolumn{3}{|l|}{ Acute GVHD II-IV } \\
\hline MICB98 matching (mismatches) & $1.47(1.05-2.07)$ & 0.025 \\
\hline CMV status $(\mathrm{D}+/ \mathrm{R}-$ or $\mathrm{D}-/ \mathrm{R}+$ or $\mathrm{D}+/ \mathrm{R}+) \ddagger$ & $1.18(0.92-1.51)$ & 0.2 \\
\hline Interaction: MICB98 matching X CMV status & $0.57(0.29-1.10)$ & 0.095 \\
\hline \multicolumn{3}{|l|}{ Acute GVHD III-IV } \\
\hline MICB98 matching (mismatches) & $3.63(3.15-4.18)$ & $<0.001$ \\
\hline CMV status ( $\mathrm{D}+/ \mathrm{R}-$ or $\mathrm{D}-/ \mathrm{R}+$ or $\mathrm{D}+/ \mathrm{R}+)$ & $1.50(1.15-1.96)$ & 0.003 \\
\hline Interaction: MICB98 matching X CMV status & $0.26(0.17-0.40)$ & $<0.001$ \\
\hline \multicolumn{3}{|l|}{ Chronic GVHD } \\
\hline MICB98 matching (mismatches) & $1.26(1.25-1.27)$ & $<0.001$ \\
\hline CMV status ( $\mathrm{D}+/ \mathrm{R}-$ or $\mathrm{D}-/ \mathrm{R}+$ or $\mathrm{D}+/ \mathrm{R}+)$ & $1.34(1.15-1.56)$ & $<0.001$ \\
\hline Interaction: MICB98 matching X CMV status & $0.91(0.70-1.18)$ & 0.48 \\
\hline \multicolumn{3}{|l|}{ Relapse $^{\dagger}$} \\
\hline MICB98 matching (mismatches) & $0.89(0.78-1.01)$ & 0.073 \\
\hline CMV status ( $\mathrm{D}+/ \mathrm{R}-$ or $\mathrm{D}-/ \mathrm{R}+$ or $\mathrm{D}+/ \mathrm{R}+)$ & $0.77(0.70-0.84)$ & $<0.001$ \\
\hline Interaction: MICB98 matching X CMV status & $2.61(1.79-3.82)$ & $<0.001$ \\
\hline \multicolumn{3}{|l|}{ Overall survival } \\
\hline MICB98 matching (mismatches) & $0.80(0.64-1.00)$ & 0.054 \\
\hline CMV status ( $\mathrm{D}+/ \mathrm{R}-$ or $\mathrm{D}-/ \mathrm{R}+$ or $\mathrm{D}+/ \mathrm{R}+)$ & $1.16(1.14-1.19)$ & $<0.001$ \\
\hline Interaction: MICB98 matching X CMV status & $1.53(1.38-1.69)$ & $<0.001$ \\
\hline \multicolumn{3}{|l|}{ Relapse-free survival } \\
\hline MICB98 matching (mismatches) & $0.78(0.70-0.86)$ & $<0.001$ \\
\hline CMV status ( $\mathrm{D}+/ \mathrm{R}-$ or $\mathrm{D}-/ \mathrm{R}+$ or $\mathrm{D}+/ \mathrm{R}+)$ & $1.09(1.05-1.13)$ & $<0.001$ \\
\hline Interaction: MICB98 matching X CMV status & $1.57(1.45-1.70)$ & $<0.001$ \\
\hline \multicolumn{3}{|l|}{ Non-relapse mortality } \\
\hline MICB98 matching (mismatches) & $1.14(0.46-2.86)$ & 0.78 \\
\hline CMV status ( $\mathrm{D}+/ \mathrm{R}-$ or $\mathrm{D}-/ \mathrm{R}+$ or $\mathrm{D}+/ \mathrm{R}+)$ & $1.38(1.12-1.70)$ & 0.003 \\
\hline Interaction: MICB98 matching X CMV status & $0.41(0.22-0.76)$ & 0.005 \\
\hline
\end{tabular}

Results are presented as Hazard Ratios with 95\% confidence intervals (CI). GVHD: Graftversus-host disease. * All models were adjusted for patient's age, patient-donor sex, patientdonor serological status for cytomegalovirus, year of transplantation, time to transplantation, transplantation center, source of stem cells, conditioning regimen, GVHD prophylaxis, treatment with anti-thymocyte globulin or Alemtuzumab, HLA-DPB1 matching status, disease category and severity at transplantation. † Transplantations performed for non-malignant diseases were excluded from the analysis. $\ddagger D$ and $R$ stand for donor and recipient, respectively. The reference category for the CMV status is D-/R-. 


\begin{tabular}{|c|c|c|}
\hline & hazard ratio $(95 \% \mathrm{Cl})^{*}$ & $P$-value \\
\hline \multicolumn{3}{|l|}{ GVHD } \\
\hline \multicolumn{3}{|l|}{ Chronic } \\
\hline Absent $(n=307)$ & Ref. & - \\
\hline Present $(n=169)$ & $0.99(0.83-1.19)$ & 1.05 \\
\hline \multicolumn{3}{|l|}{ Acute III-IV } \\
\hline Absent $(n=388)$ & Ref. & - \\
\hline Present $(n=78)$ & $1.12997(1.1290-1.13)$ & $<0.001$ \\
\hline \multicolumn{3}{|l|}{ MICB98 matching } \\
\hline Matched $(n=437)$ & Ref. & - \\
\hline Mismatched $(n=19)$ & $1.84(1.34-2.51)$ & $<0.001$ \\
\hline
\end{tabular}

Only the pairs in which the donor and/or the recipient was/were positive for CMV pre-

734 HCT were included in the analysis. The results are presented as Hazard Ratios with

735 95\% confidence intervals (Cls). GVHD: Graft-versus-host disease. Ref.: Reference category. * Multivariate Fine and Gray model including MICB98 matching, acute GVHD III-IV and chronic GVHD as time-dependent covariates in the model. In 738 addition, the model was adjusted for patient's age, patient-donor sex, patient-donor 739 serological status for cytomegalovirus, year of transplantation, time to transplantation, transplantation center, source of stem cells, conditioning regimen, GVHD prophylaxis,

741 treatment with anti-thymocyte globulin or Alemtuzumab, HLA-DPB1 matching status, 742 disease category and severity at transplantation. 
Figure 1

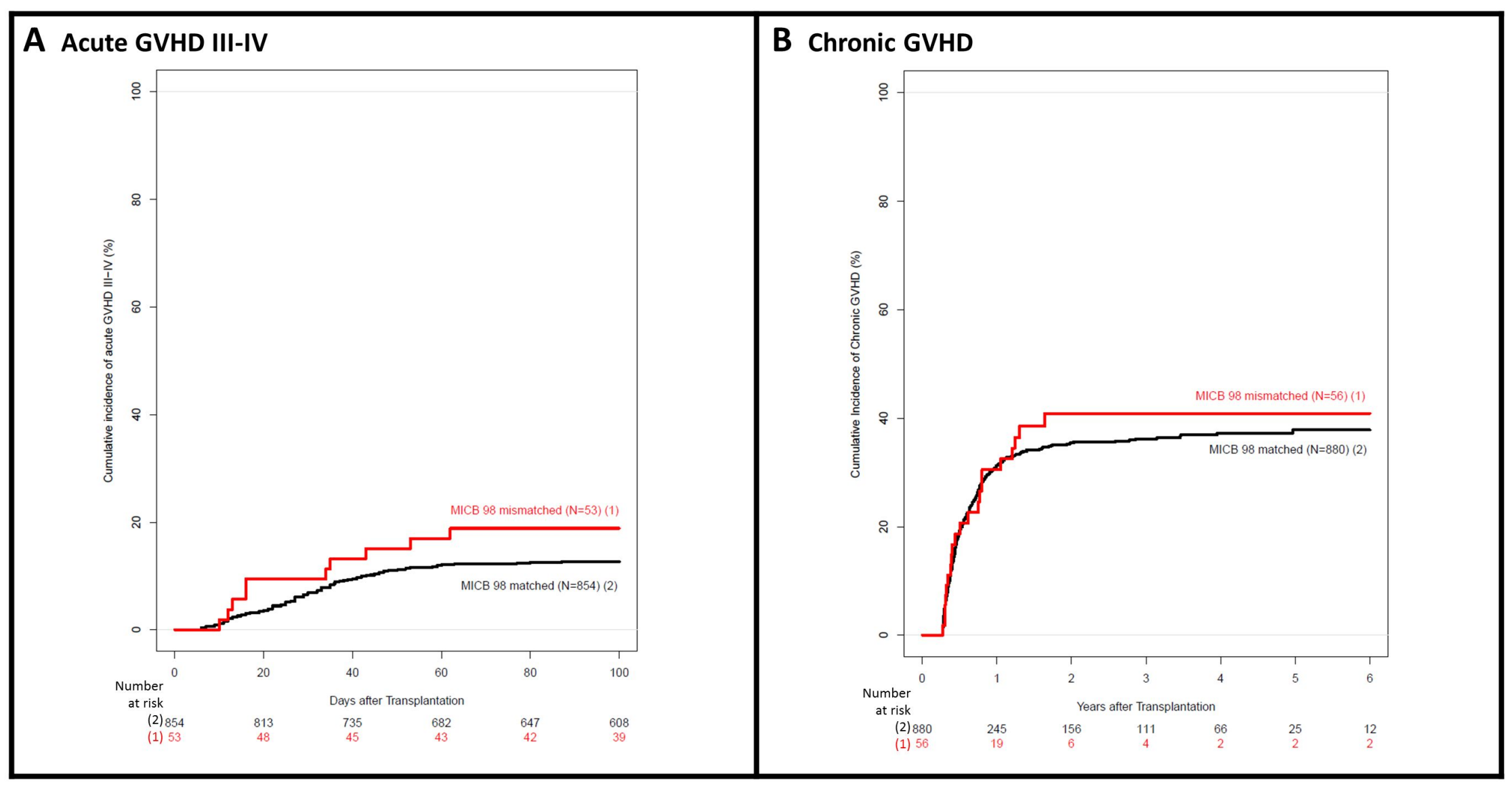


A Acute GVHD III-IV in HCT with donors and recipients negative for $\mathrm{CMV}$

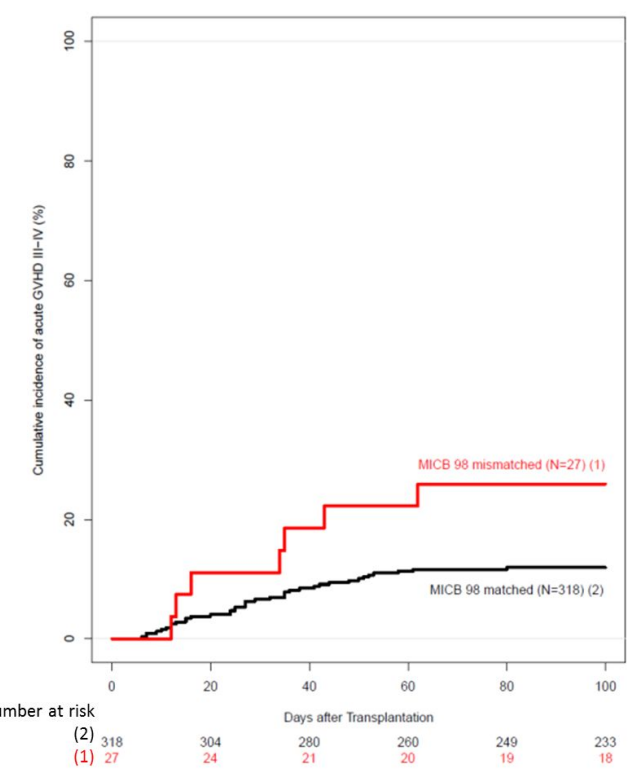

C Overall Survival in MICB98 matched HCT

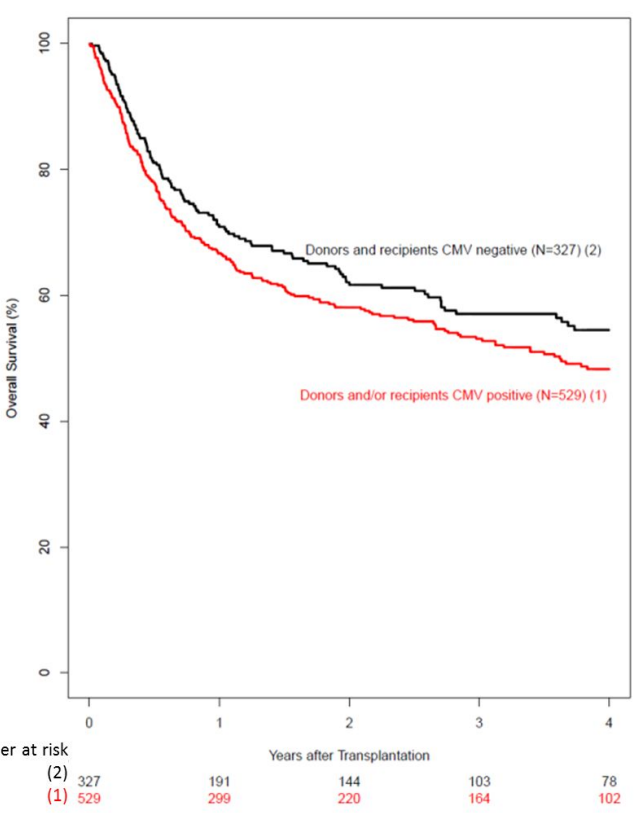

B Acute GVHD III-IV in HCT with donors and/or recipients positive for $\mathrm{CMV}$

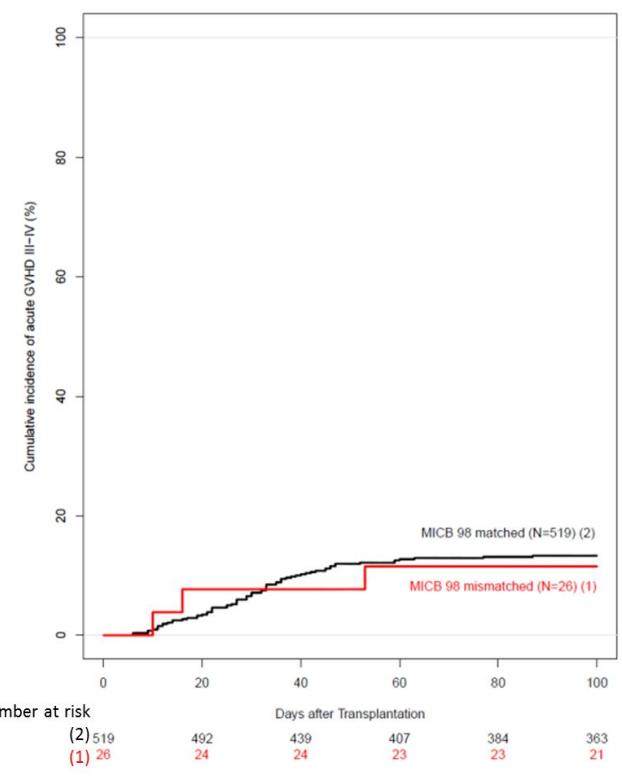

D Overall Survival in MICB98 mismatched HCT

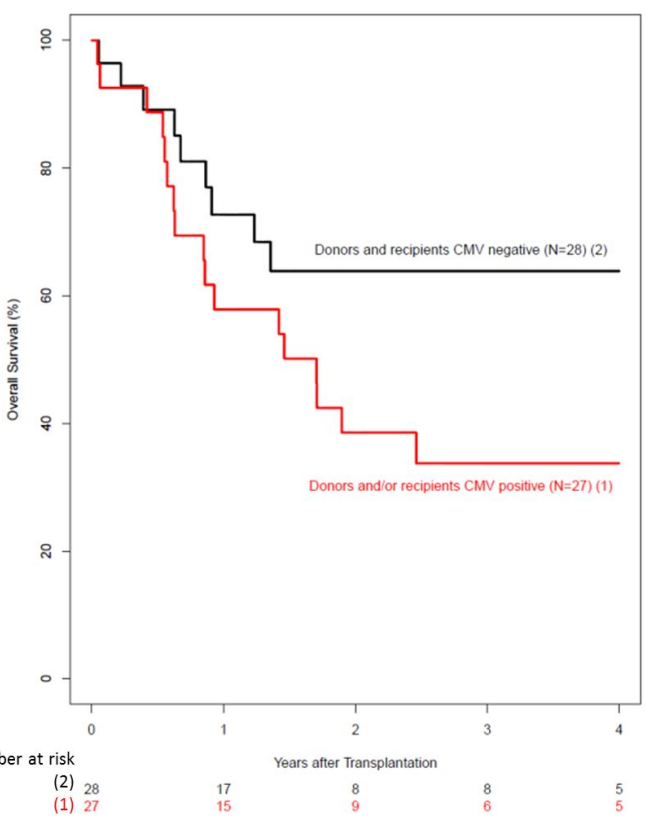


Figure 3

CMV reactivation in HCT with donor and/or recipients positive for $\mathrm{CMV}$

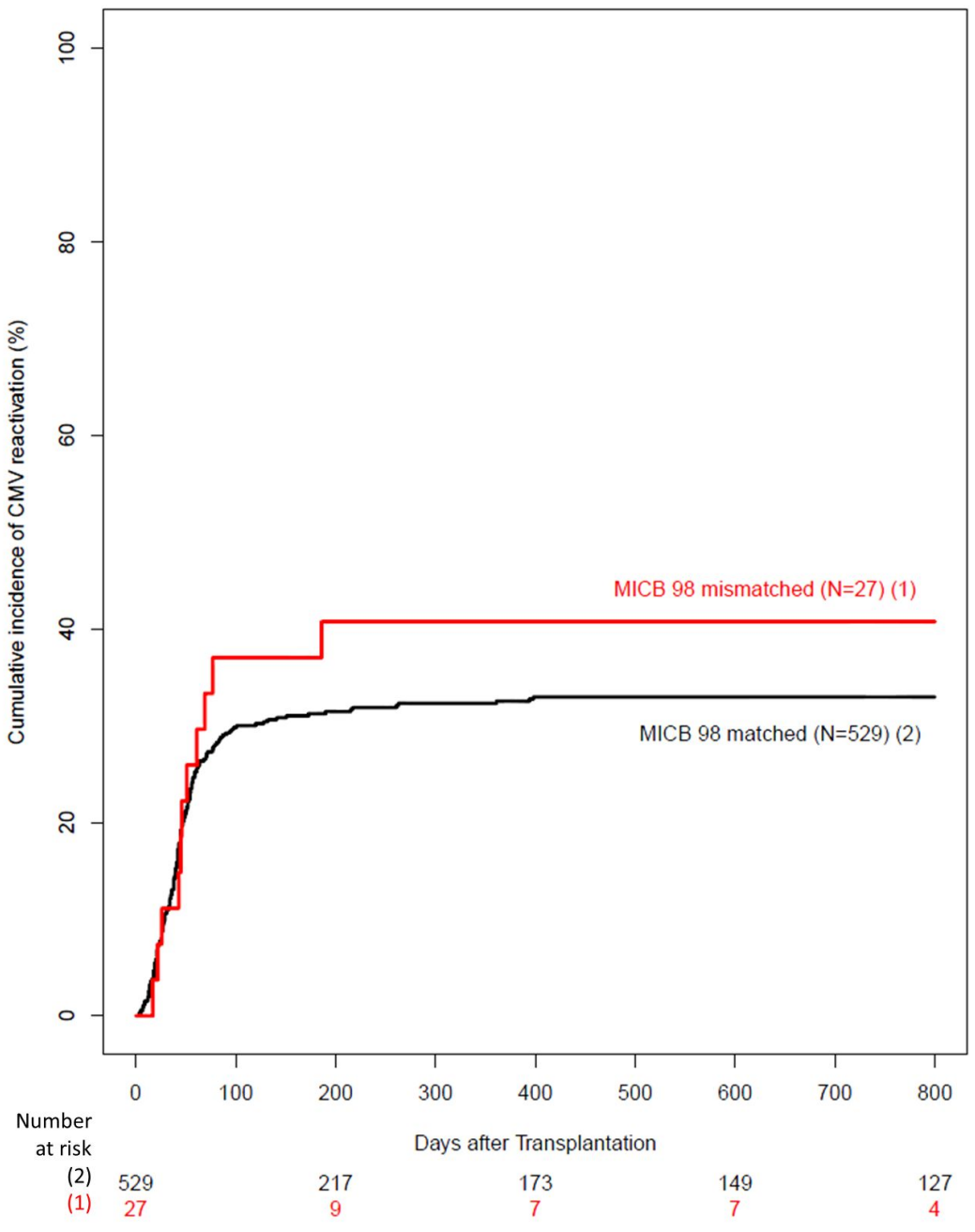

